\title{
Cyclostratigraphy and paleoenvironmental inference from downhole logging of sediments in tropical Lake Towuti, Indonesia
}

\author{
A. Ulfers $\mathbb{D} \cdot$ K. Hesse $\cdot$ C. Zeeden $\cdot$ J. M. Russell $\cdot$ H. Vogel $\cdot$ S. Bijaksana \\ T. Wonik
}

Received: 19 March 2020/ Accepted: 28 December 2020/Published online: 12 February 2021

(C) The Author(s) 2021

\begin{abstract}
Lake Towuti is located on central Sulawesi/Indonesia, within the Indo Pacific Warm Pool, a globally important region for atmospheric heat and moisture budgets. In 2015 the Towuti Drilling Project recovered more than $1000 \mathrm{~m}$ of drill core from the lake, along with downhole geophysical logging data from two drilling sites. The cores constitute the longest continuous lacustrine sediment succession from the Indo Pacific Warm Pool. We combined lithological descriptions with borehole logging data and used multivariate statistics to better understand the
\end{abstract}

Supplementary Information The online version of this article (https://doi.org/10.1007/s10933-020-00171-9) contains supplementary material, which is available to authorized users.

A. Ulfers $(\bowtie) \cdot$ K. Hesse · C. Zeeden · T. Wonik Leibniz Institute for Applied Geophysics, Stilleweg 2, 30655 Hannover, Germany

e-mail: Arne.Ulfers@leibniz-liag.de

K. Hesse

e-mail: Katja.Hesse@leibniz-liag.de

C. Zeeden

e-mail: Christian.Zeeden@leibniz-liag.de

T. Wonik

e-mail: Thomas.Wonik@leibniz-liag.de

\section{J. M. Russell}

Department of Earth, Environmental, and Planetary Sciences, Brown University, Box 1846, Providence, RI 02912, USA

e-mail: James_Russell@brown.edu cyclic sequence, paleoenvironments, and geochronology of these sediments. Accurate chronologies are crucial to analyze and interpret paleoclimate records. Astronomical tuning can help build age-depth models and fill gaps between age control points. Cyclostratigraphic investigations were conducted on a downhole magnetic susceptibility log from the lacustrine facies (10-98 m below lake floor) from a continuous record of sediments in Lake Towuti. This study provides insights into the sedimentary history of the basin between radiometric ages derived from dating a tephra layer $(\sim 797 \mathrm{ka})$ and $\mathrm{C}^{14}$-ages $(\sim 45 \mathrm{ka})$ in the cores. We derived an age model that spans from late marine isotope stage (MIS) 23 to late MIS 6

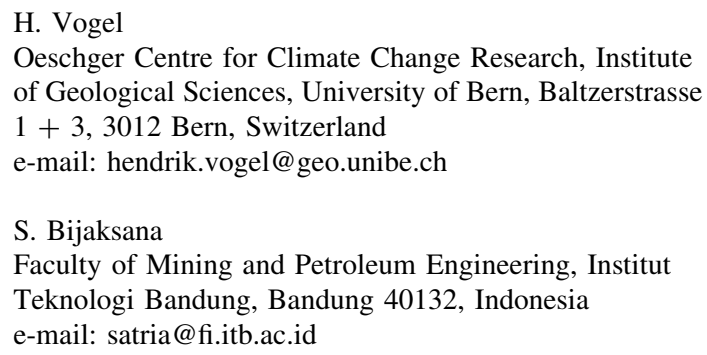


$(903 \pm 11$ to $131 \pm 67 \mathrm{ka})$. Although uncertainties caused by the relatively short record and the small differences in the physical properties of sediments limited the efficacy of our approach, we suggest that eccentricity cycles and/or global glacial-interglacial climate variability were the main drivers of local variations in hydroclimate in central Indonesia. We generated the first nearly complete age-depth model for the lacustrine facies of Lake Towuti and examined the potential of geophysical downhole logging for time estimation and lithological description. Future lake drilling projects will benefit from this approach, since logging data are available just after the drilling campaign, whereas core descriptions, though more resolved, only become available months to years later.

Keywords Paleoclimate - Geophysical downhole logging · Cyclostratigraphy · Lake Towuti · Indo Pacific Warm Pool

\section{Introduction}

Lake Towuti is part of the Malili Lake System in central Sulawesi, Indonesia. It is located within the Indo Pacific Warm Pool (IPWP), one of the most relevant regions for global climate variability on Earth. With sea surface temperatures of $\sim 28^{\circ} \mathrm{C}$ throughout the year, the IPWP introduces large amounts of heat and moisture into the atmosphere, such that it dominates not only Southeast Asia, but also affects climate on a global scale. The climate (temperature and precipitation) on Sulawesi is the result of interactions between the Australasian monsoons, the El Niño-Southern Oscillation, the Intertropical Convergence Zone (ITCZ), and warm sea surface temperatures (An 2000; De Deckker 2016; Konecky et al. 2016; Wang et al. 2008; Yan et al. 1992). Equatorial regions and the western Pacific had not yet been a focus of "International Continental Scientific Drilling Program" (ICDP) campaigns. One of the main objectives of the "Towuti Drilling Project" (TDP) was to provide a high-resolution record of the tropical western Pacific during the Pleistocene and to understand climate/hydrological and environmental changes in this globally important region. Lake Towuti meets the criteria to address those questions since it is the largest tectonic lake in Southeast Asia and is thought to contain a continuous, undisturbed sediment succession spanning the last $\sim 1 \mathrm{Ma}$ (Russell and Bijaksana 2012; Russell et al. 2016).

The TDP is an international research program conducted under the ICDP to understand: (1) longterm climate and environmental change in the tropical western Pacific, (2) impacts of geological and environmental changes on the biological evolution of aquatic taxa, and (3) geomicrobiology and biogeochemistry of metal-rich, ultramafic-hosted lake sediments (Russell et al. 2016). After pre-site surveys between 2007 and 2013, three drill sites were selected using results from seismic surveys and short piston cores (Russell and Bijaksana 2012). To achieve the main objectives, the ICDP drilling campaign was conducted in May-July 2015, using the ICDP Deep Lakes Drilling System (DLDS), operated by DOSECC Exploration Services. A total of $\sim 1018 \mathrm{~m}$ of sediment core was recovered from three sites, and downhole geophysical logging measurements were obtained from two sites. The longest, undisturbed, lacustrine sediment succession appears in the upper $98 \mathrm{~m}$ of Site 1. It consists mainly of two different, well-stratified clay types, and only minor layers of turbidite-like mass movement deposits (MMD) or thin tephra layers. Below $98 \mathrm{~m}$, sediments consist of silts, with layers of peat and sand/gravel, indicating a prelacustrine facies. At Site 2, the upper $73 \mathrm{~m}$ are characterized by MMD, but below $73 \mathrm{~m}$, the sediments are similar to those in the upper $98 \mathrm{~m}$ at Site 1 (Russell et al. 2016).

A robust age-depth model of the sediment succession in Lake Towuti is critical to determine the timing of paleoclimate changes, the rates of biological evolution and biogeochemical cycling in the lake and its sediments. Site 1 meets essential criteria to estimate such models for the complete succession: (1) Radiocarbon dates on 23 samples of organic carbon from short piston cores taken close to Site 1 reveal a maximum age of $\sim 45 \mathrm{ka}$ at $9 \mathrm{~m}$ below lake floor (mblf) (Russell et al. 2014), (2) one ${ }^{40} \mathrm{Ar} /{ }^{39} \mathrm{Ar}$-dated volcanic ash layer at $\sim 72$ mblf (tephra 18, T18) has an age of $797.3 \pm 1.6 \mathrm{ka}$ (Russell et al. 2020), and (3) quasi-rhythmic alternation of two clay types probably reflects environmental changes that resulted from orbital-scale changes in insolation and continental ice volume (Russell et al. 2020). Other factors, however, including hydrological changes and the active tectonic setting, are capable of influencing sedimentology in 
Lake Towuti and should be considered during interpretations.

For sediment age estimates, we focused on the magnetic susceptibility (MS) record of Site 1, where, in contrast to Site 2, occurrence of MMD is minor. To minimize overestimation of sedimentation rates, segments containing MMD were excluded from the record before cyclostratigraphic analysis. The two clay types that represent most of the lacustrine facies at Site 1 are distinguishable by MS, and in short piston cores MS reflects environmental changes in the sedimentary system linked to glacial/interglacial variability (Russell et al. 2020; Tamuntuan et al. 2014).

This study aimed to: (1) infer sedimentary processes in Lake Towuti from downhole geophysical logging data, (2) establish a chronology for the sediment record at Site 1 by supplementing the radiometric dates between 797 and $\sim 45 \mathrm{ka}$, and (3) investigate the potential influence of long-term insolation cycles on the undisturbed sediment successions in Lake Towuti.

\section{Background}

The geology of central Sulawesi is characterized by ultramafic rocks and lateritic soils. The Malili Lakes catchments are generally underlain by heavy-metalrich, trace-metal-poor ultramafic rock. Notable exceptions include limestones that partially underlie southwestern Lake Matano, and a metasedimentary complex southeast of Lake Towuti (Costa et al. 2015; Fig. 1a, b). Today the lake is weakly, though permanently stratified, and ultra-oligotrophic, with anoxic conditions below $\sim 120 \mathrm{~m}$ water depth (Vuillemin et al. 2016). Two distinctive facies were identified in seismic profiles prior to drilling (Fig. 1d): a lower Unit 2, interpreted as fluviolacustrine sediment, and an upper Unit 1, composed of betterstratified lacustrine sediment (Russell et al. 2016).

During the last glacial maximum (LGM), the region around the Malili Lake System was drier and the decreased precipitation caused lower water level than today (Russell et al. 2014; Vogel et al. 2015; Wicaksono et al. 2015). The water level and the oxic/anoxic boundary decreased simultaneously. Combined with stronger circulation of the water column, this resulted in increased oxygenation at the sediment water interface, which induced changes in the sediment geochemistry and initiated authigenic formation of magnetite and siderite (Tamuntuan et al. 2014). In contrast, enhanced precipitation during wet climate conditions, e.g. during MIS 1 and parts of MIS 3 (Russell et al. 2014) did not only induce higher water levels, resulting in more pronounced stratification of the water body (oxic in surface waters/anoxic in bottom waters), but also enhanced input of organic material, causing an anoxic environment that led to dissolution of magnetite in the sediments. Hence, the magnetic properties of sediments are regulated by a combination of changes in detrital influx, iron oxide dissolution under reducing conditions and the precipitation of magnetite and siderite (Costa et al. 2015; Tamuntuan et al. 2014; Russell et al. 2014). The result was an alternation of deposition of two main clay types in Lake Towuti: (1) Reddish "sideritic clay" was characteristic of oxic conditions, contains magnetite, and shows enhanced siderite and MS, compared to (2) green clay, referred to simply as "clay," which is characteristic of anoxic conditions and lower MS. In addition to the main clay types, 3-5-m-thick layers of diatomaceous ooze occur at all sites. A lack of siderite and low MS is characteristic of these layers, which consist primarily of planktonic diatoms. Multiple thin layers of MMD, consisting of normally graded silts $(<0.5 \mathrm{~m})$ and tephra (usually $<20 \mathrm{~cm}$ ), are distributed throughout the sediment successions and can cause distinct peaks in MS (Russell et al. 2016, 2020). Rock magnetic properties of lacustrine sediments have been used in previous studies to detect paleoenvironmental changes in lakes (Gebhardt et al. 2013; Stockhausen and Zolitschka 1999; Melles et al. 2012). In Lake Towuti, magnetic susceptibility measurements were carried out on sediments from an 11-m piston core, obtained as part of a pre-site survey in 2013. MIS 3 and 1 represent wet climate conditions and are marked by low magnetic susceptibility, whereas the drier MIS 2 is characterized by high susceptibility values (Tamuntuan et al. 2014). Assuming this relation continues with depth, together with the observation that initial data from the long ICDP core and borehole logging show clear indications of orbital-scale climate variability during the middle to late Pleistocene (Russell et al. 2016), it is likely that magnetic susceptibility values from downhole measurements are a promising variable that can be used to investigate long-term climate change around Lake Towuti. 
(a)

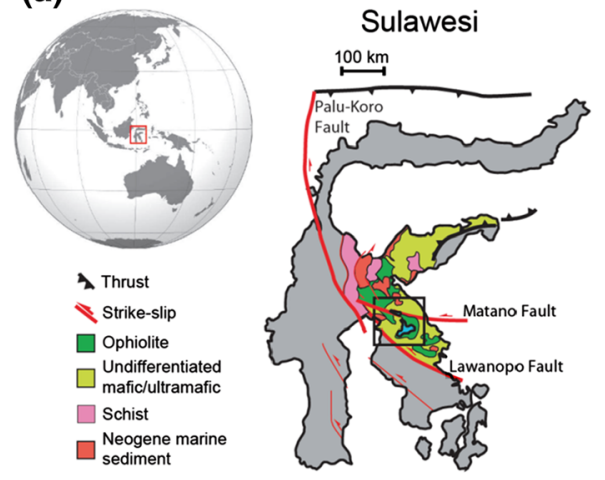

(c)

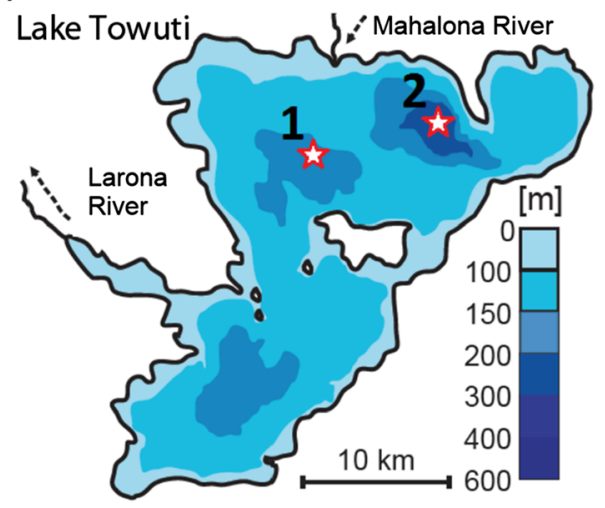

(b)

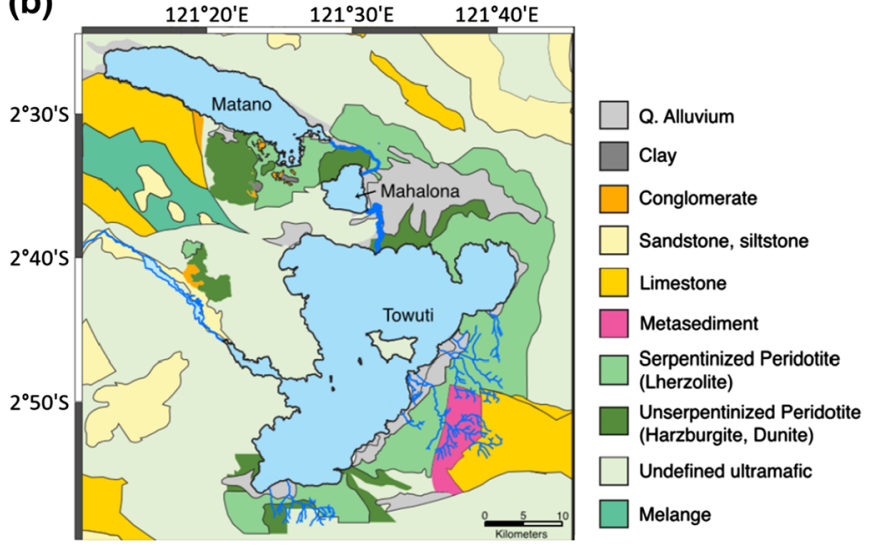

(d)

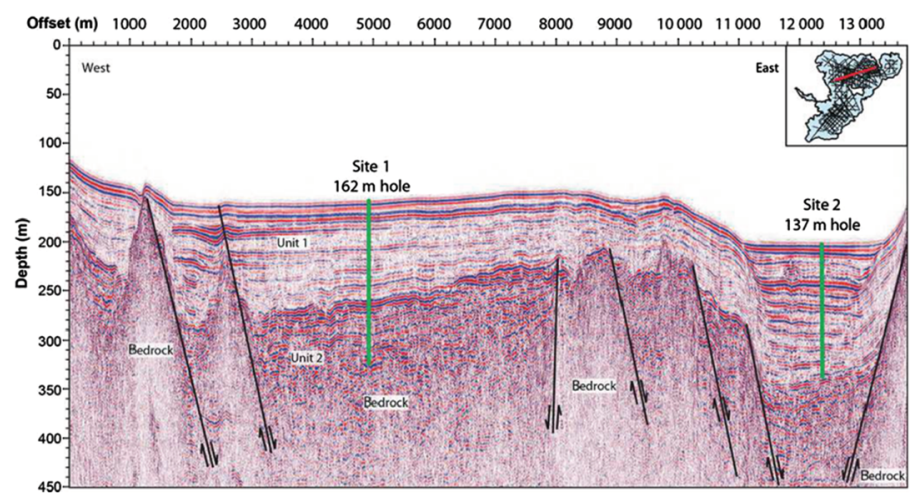

Fig. 1 a Geological map of Central Sulawesi, b detailed geological map of the Malili Lake System, c bathymetric map of Lake Towuti and $\mathbf{d}$ seismic reflection data from pre-site surveys,

\section{Materials and methods}

\section{Coring sites and core descriptions}

Fieldwork was conducted in May-July 2015. Boreholes were drilled using a PQ-type drill string ( $\varnothing$ $122.6 \mathrm{~mm}$ hole, $\varnothing 66 \mathrm{~mm}$ sediment core; Russell et al. 2016). The coring sites were selected using seismic data and piston cores that span the last glacial/ interglacial cycles (MIS 3-1; Russell et al. 2014). Objectives at Site 1, in the central northern basin, were to retrieve a continuous, turbidite-poor, lacustrine record of Unit 1. For Site 2, the goal was to investigate changes in deltaic sedimentation processes, forced by lake-level fluctuations and possible changes in the river system in the deepest part of the lake, close to the Mahalona River (Fig. 1c). A third site was planned in the southern basin, but, due to organizational showing profile through both sites. Logging locations indicated by red stars (modified from Russell et al. 2016 and Costa et al. 2015)

problems, finally drilled $\sim 1.5 \mathrm{~km}$ west of Site 1 (Russell et al. 2016; Vogel et al. 2015). Site 3 is not part of this study, since no geophysical downhole logging was conducted there.

At Site 1, five cores $(1 \mathrm{~A}-1 \mathrm{~F})$ were drilled, with a maximum depth of $\sim 162$ mblf achieved at Site 1B where $0.4 \mathrm{~m}$ of lithified conglomerate, representing the bedrock, was retrieved. Seismic surveys, together with initial core descriptions, enabled division of the succession into two main units (Figs. 1d, 3). Unit 2 (from 161 to 98 mblf; Fig. 1d) is characterized by silty and/or sandy sediment, interbedded with peat $(1.5 \mathrm{~m}$ thick maximum), or minor gravel layers $(<0.7 \mathrm{~m}$ thick). The upper $\sim 98 \mathrm{~m}$ represent the lacustrine facies (Unit 1) and are characterized by alternating clay and sideritic clay (Russell et al. 2016, 2020). Unit 1 also includes two thick layers of diatomaceous ooze, intercalated between the clays ( 3 and $5 \mathrm{~m}$ thick each) 
and multiple thin tephra layers $(<20 \mathrm{~cm})$ and MMD $(<50 \mathrm{~cm})$. Core recovery differed among the five drill holes (79-99\%), with loss occurring almost exclusively in lower Unit 2 (Russell et al. 2016).

At Site 2, three cores $(2 \mathrm{~A}-2 \mathrm{C})$ were drilled, to a maximum depth of 138 mblf at Site 2A (Fig. 1d; Electronic Supplementary Material [ESM] Fig. S2). The drilling target was reached at 133 mblf, where the transition from Unit 2 to Unit 1 is located. The lower part of Unit 1 (from 133 to 70 mblf) consists of lacustrine material comparable to the clay/sideritic clay alternation seen at Site 1, Unit 1 (Russell et al. 2016). The upper $70 \mathrm{~m}$ are dominated by normally graded silts (MMD with $0.8 \mathrm{~m}$ thickness maximum) and contain up to 3-m-thick tephras. These tephras are much thicker than those observed at Site 1, possibly because they contain reworked material associated with MMD. Core recovery differed among the three drill holes (83-99\%; Russell et al. 2016).

Physical properties of sediments

Downhole geophysical logging was conducted at Sites $1 \mathrm{~B}, 1 \mathrm{~F}$, and $2 \mathrm{C}$, using a set of downhole logging equipment provided by the Leibniz Institute for Applied Geophysics (Fig. 2; Table 1). These included

\section{Site $1 \mathrm{~B}$ Site $1 \mathrm{~F}$}

Site 2C

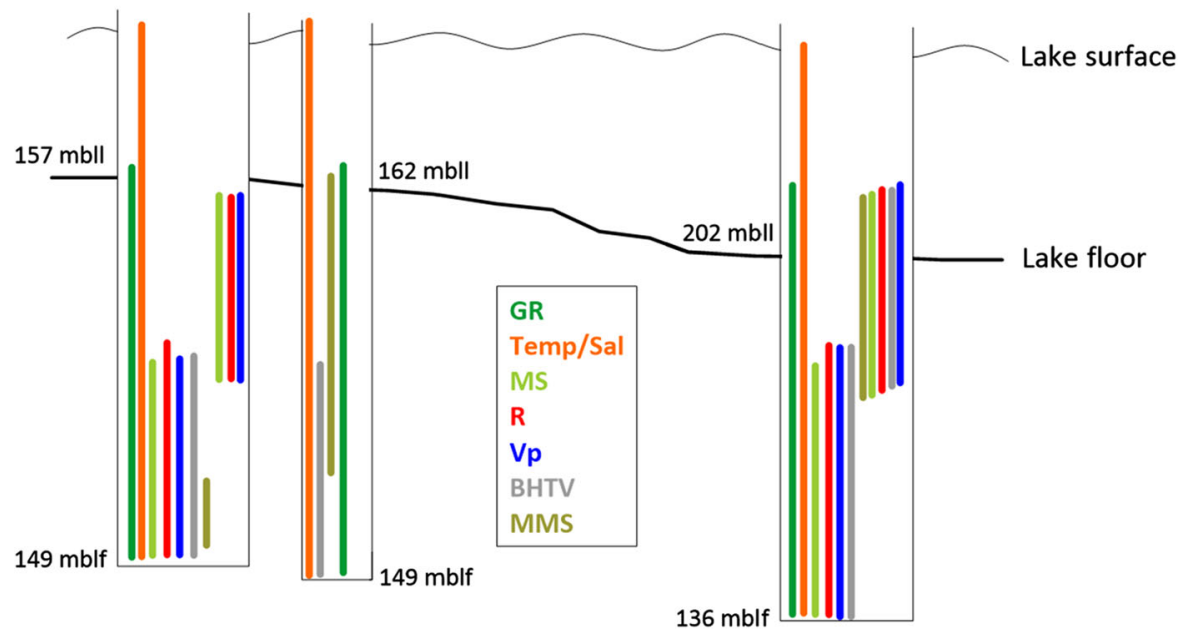

Fig. 2 Logging scheme at Sites $1 \mathrm{~B} / \mathrm{F}$ and $2 \mathrm{C}$. First, specific variables were measured through the drill pipe (spectral gamma ray, temperature and salinity). Then, drill pipes were pulled out partly to sustain hole stability in the upper part, but open-hole conditions for the measurements in the lower section. For the second run, drill pipes were pulled almost completely from the hole . $\mathrm{mbll}=$ meters below lake level; mblf $=$ meters below lake floor. Abbreviations of logged variables are shown in Table 1

Table 1 Downhole logging tools used at Lake Towuti

\begin{tabular}{lll}
\hline Downhole logging tool & Measured parameter & Abbreviation \\
\hline Spectral Gamma Ray Sonde SGR 70, type 1419, Antares & Natural gamma radiation, U-, Th-, K-concentration & GR \\
Susceptibility Sonde, type 1108, Antares & Magnetic susceptibility & MS \\
Dual Laterolog Sonde, Antares & Resistivity (Rdeep \& Rshallow) & R \\
Sonic Sonde, Antares & Acoustic velocity & Vp \\
BHTV-FAC40 Televiewer, ALT & Acoustic imaging of borehole-wall & BHTV \\
Dipmeter ADIP A21, Antares & Caliper, orientation of borehole, dip of strata & Dip \\
Micro-susceptibility instrument, type 1121, Antares & Magnetic susceptibility & MMS \\
Salinity/temperature Sonde, Antares & Salinity and temperature of borehole fluid & Temp/sal \\
\hline
\end{tabular}


spectral gamma ray (GR; including $\mathrm{U}, \mathrm{K}$ and $\mathrm{Th}$ concentrations), magnetic susceptibility (MS), resistivity (R), sonic velocity (Vp), dipmeter (Dip) and ultrasonic imaging of the borehole walls. Since all measurements, except spectral gamma ray, need an open hole, drill pipes were pulled successively after each run (Fig. 2). Geophysical datasets were recorded and partly pre-processed on site, using the software Geobase $^{\circledR}$ (Antares, Germany).

Further processing was conducted using Wellcad $($ ) (Advanced Logic Technology, Luxembourg). The whole-core logging datasets for cores from each of the three holes were adjusted to match the depths from borehole logging data and spliced to generate complete downhole logs (Fig. 3). Matching magnetic susceptibility data from multi-sensor core logging (MSCL) and downhole logging measurements enabled correlation of the sediment core to true depth measured from downhole logging, referred to as "meters below lake floor" (mblf). This also enabled matching core descriptions and logging data. Instantaneously deposited layers like tephras and MMD, referred to as "event layers," can confound signals used for cyclostratigraphic analysis (described below) if they are thick enough, and therefore have to be "removed" from the record. Overall, more than 20 tephra layers with thicknesses between 0.7 and $19.3 \mathrm{~cm}$, and about 20 MMDs, from 1.5 to $46.5 \mathrm{~cm}$ thick, were described in the sediments from the lacustrine facies (Unit 1) at Site 1B. Exclusion of event layers leads to artificial shortening of the cored succession and thus to a synthetic depth ("depth*"). In the case of data from the lacustrine facies at Site 1B, the total depth shrinking represents $3.65 \mathrm{~m}$ of the total $98 \mathrm{~m}$.

To limit the influence on calculations caused by diagenetic processes or post-drilling effects, downhole logs were linearly detrended. The consequence is that absolute measured values were converted to values relative to the median. The mentioned effects can cause trends in downhole logs with depth, which in turn may be problematic for statistical analyses. Such effects include compaction (generally increases with depth) or interaction of drilling fluids with the borehole wall (increases with time of sediment exposure to fluids). For example, the R-log at site 1B shows an increasing linear upward trend toward the lake bottom (Fig. 3). Higher values at the top of the log can be explained by lake water intrusion into the
Fig. 3 Downhole logging variables, core description (*Lithology description is simplified here, for more information see Russell et al. 2016) and water content of NMR laboratory measurements from Site 1B. All logs are raw data. A change in physical variables at $\sim 98$ mblf indicates the transition from pre-lacustrine to lacustrine facies. Depth in meters below lake floor (mblf). $G R$ total gamma radiation with concentrations of $\mathrm{U}$, Th and K; $M S$ magnetic susceptibility; $R$ resistivity; $V p$ acoustic velocity; Sal salinity; Temp temperature; Wc total total water content

borehole. Vuillemin et al. (2016) and Lehmusluoto et al. (1995) reported the conductivity of Lake Towuti's water varies between 175 and $400 \mu \mathrm{S} / \mathrm{cm}$ (57 $\Omega \mathrm{m}$ and $25 \Omega \mathrm{m}$, respectively). Migration of these waters into the drill hole and partly into the sediments, can result in higher measured R-values.

Cluster analysis was performed to construct continuous, artificial logs, based on their physical properties derived from detrended downhole logging data (GR, Th/K-ratio, MS, R, Vp). The software utilized was the WinSTAT ${ }^{\circledR}$ software for Microsoft ${ }^{\circledR}$ Excel and the cluster distance measure used was Ward's method (Ward Jr 1963). Based on the resulting dendrogram, a specific number of classes was defined and average values for logging variables were calculated for each class. Analyses were conducted for complete-depth $\operatorname{logs}$ or shorter sections of special relevance (i.e. 10-98 mblf at Site 1B, representing the lacustrine facies). Since not all variables were available for all sites and depths (Fig. 2), several configurations of variables and methods were tested to achieve a useful classification of sediments.

\section{Cyclostratigraphy}

Results were generated using the 'astrochron' package for the R programming language (Meyers 2014; R Core Team 2020). Amplitude spectra were created for intervals of interest. Tracking high-amplitude peaks and relating these to the 110-ka eccentricity (the combination of the 95-ka and 125-ka cycles), the 41ka obliquity and the 21-ka precession cycles can be used to determine fluctuations in sedimentation rates over depth, assuming these cycles control sedimentation (Eq. 1). Sedimentation rates $(S R$ in $\mathrm{cm} / \mathrm{ka})$ for each depth can be calculated using the period ( $P$ in ka) of the assumed orbital cycle and the frequency ( $f$ in $1 /$ m) tracked in the amplitude spectra. 


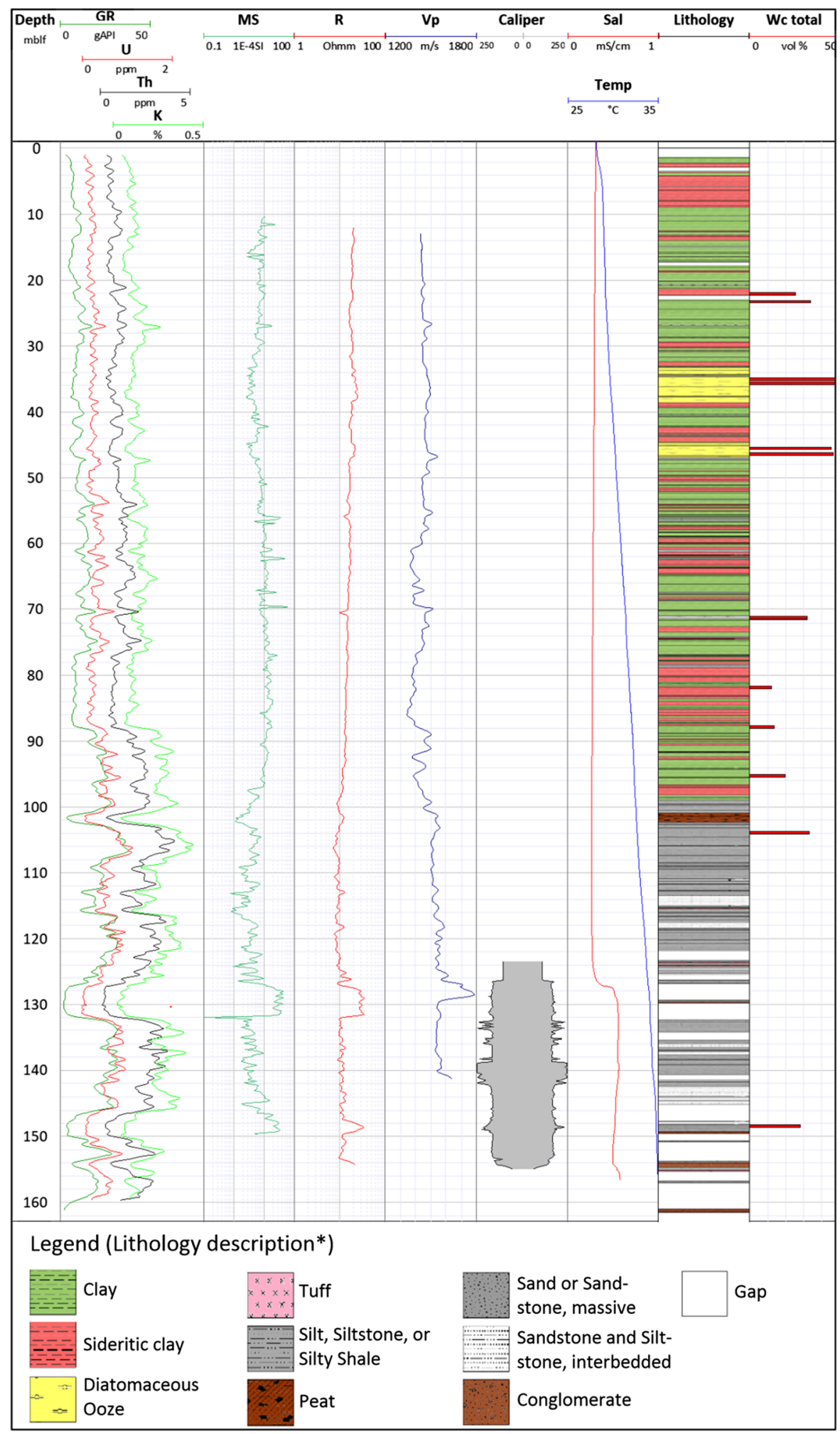


$S R=\frac{100}{P} * f$

Together with radiometric age control points, the SR calculations lead to an age-depth model for the Lake Towuti record. After examining the logging variables, astrochronological analyses were conducted using the MS from downhole logging measurements because it appears to reflect orbital cycles most clearly and distinguishes between the major sediment types, i.e. clay and sideritic clay. The relative age-depth estimations from cyclostratigraphic analysis are anchored to absolute ages derived from radiometric dating. In Lake Towuti, this reference value is a tephra (T18) at a depth* of 72.05 with an age of $797.3 \pm 1.6 \mathrm{ka}$ (Russell et al. 2020). Additionally, $23{ }^{14} \mathrm{C}$ measurements from a piston core close to Site 1 indicate more rapid sedimentation rates in the upper $9 \mathrm{~m}$ of the sediments. The oldest ${ }^{14} \mathrm{C}$ age in this core is $\sim 45 \mathrm{ka}$ at $\sim 9$ mblf (Russell et al. 2014).

Event layers (MMD and tephra) are instantaneous deposits and contain a negligible amount of time with respect to cyclostratigraphic determination. Event layers, if not removed from the record, would lead to an overestimation of sedimentation rates (see "Physical properties of sediments"). Even after removing the event layers, the data still contain artefacts of these events caused by the slopes of the peaks originating from these layers. Those border effects were smoothed using polynomic regression (ESM Fig. S1). The importance of careful data pre-processing becomes clear when the corresponding amplitude spectra after each cyclostratigraphic processing step are compared. Smoothing of border effects has a particularly high impact on the quality of the spectra (ESM Fig. S1). The amplitude spectra were created using the slidingwindow method (Molinie and Ogg 1990; Weedon 2003). Multiple window lengths were tested to cover the widest range in the downhole logging record, with a focus on different orbital cycles.

\section{Results}

Logging features

The lower 98 mblf (Unit 2) of Site 1B are characterized by high-amplitude variations in the logged variables (Fig. 3). Changes in the sediment properties are evident at 98 mblf, at the Unit 2/Unit 1 boundary. GR, and especially MS, indicate this change by showing less distinct alternations in the upper Unit 1. Vp also decreases to values lower than $1500 \mathrm{~m} / \mathrm{s}$ instantaneously.

However, above 98 mblf (Unit 1) greatest variability is visible in GR and MS. The latter shows distinct peaks, some of which can be correlated to tephra layers and MMD in the core. Typical examples of two peaks caused by MMD occur at $\sim 62$ mblf. Those peaks can be related to MMD of $40 \mathrm{~cm}$ and $28 \mathrm{~cm}$ thickness. An example of a typical peak in MS and GR caused by tephra can be observed at $\sim 27 \mathrm{mblf}$ (Fig. 3). Low MS and high R are correlated to the beds of diatomaceous ooze. Values for $\mathrm{Vp}$ are below the velocity of sound in water $(\sim 1500 \mathrm{~m} / \mathrm{s})$ and show an increasing trend towards the top. Sideritic clay has the lowest $\mathrm{Vp}$, which contradicts the lowest porosity, measured by nuclear magnetic resonance (NMR). A similar contradiction is evident in diatomaceous ooze. There, the slightly greater $\mathrm{Vp}$ values are accompanied by high water content, i.e. high porosity.

Two vertically confined horizons in Unit 2 (132-127 and 103-101 mblf) do not follow the pattern in logging data observed elsewhere in the Site 1 stratigraphy. The deeper interval, from 132 to 127 mblf, is characterized by low GR, but considerably higher values of MS, R and $\mathrm{Vp}$, whereas the more recent, from 103 to 101 mblf, is characterized by low GR and MS. The rise in salinity of the borehole fluid at 127 mblf is noteworthy. Caliper measurements show an increase in borehole diameter at 142-139 mblf.

Site 2C shows patterns of logged variables (ESM Fig. S2) similar to Site 1, but a different lithology (Russell et al. 2016), composed of clays with two diatom layers in the lower $\sim 70$ mblf, and coarsergrain MMD in the upper part. The clayey layers in the lower part show slightly higher GR than the upper 70 mblf. MS has the largest variance in the record and decreases throughout the lower part, but increases in the upper 70 mblf. The same holds for R, although the changes are not as pronounced. In general, values for most variables in clays and MMD are rather constant, with minor trends. The first exceptions are two layers of diatomaceous ooze, which show clearly lower MS and slightly higher $\mathrm{R}$, similar to Site $1 \mathrm{~B}$. The second exceptions are tephra layers. Within the MMD, they are clearly connected to peaks in GR. This is different from tephra layers in clayey material from Site 1 or 2 , 
where the most suitable variable for this purpose is peaks in MS. Vp and R are also distinctly linked to tephra layers, but associated peaks are less evident.

Cluster analysis

\section{Site $1 B$}

Evaluation of the first cluster analyses from 141 to 13 mblf indicates a major change in lithology at $\sim 100$ mblf (ESM Table S1). This agrees with core data from Russell et al. (2016), who described a shift from a fluviolacustrine sediment (gravels, sands, peats and silts) to lacustrine and clay-rich facies around this depth.

Subsequently, cluster analyses were conducted for each unit individually (above and below $\sim 100 \mathrm{mblf}$ ) to improve characterization of sediment types. Analysis was conducted using detrended GR, MS, R, Vp and the Th/K-ratio. Clusters were divided, based on their physical properties, into four (A-D) or three classes (E-G), each representing a lithology type (Fig. 4).

\section{Cluster analysis I (Site 1B, 98-13 mblf, lacustrine facies)}

The log created from cluster analysis is dominated by classes $\mathrm{A}$ and $\mathrm{B}$, which together make up more than $90 \%$ of the upper lacustrine facies (Fig. 4, left). Class B has slightly higher GR and lower MS than class A, but in general they differ only slightly from one another. This makes it difficult to link them to core description data. Class C stands out by virtue of its high R, and represents diatomaceous ooze layers. Many thin layers of class D are distributed in the log. Although representing only $2.2 \%$ of the total $\log$, they show clearly higher values of MS and Th/K-ratio than other classes. Compared to the lithologic description from core analysis, those layers match to some of the thicker silty layers interpreted as MMD by Russell et al. (2016). Attempts to identify tephra layers by defining more classes failed, mainly as a consequence of the low thickness of tephra layers (mean thickness of $\sim 4.2 \mathrm{~cm}$ ) relative to the resolution of downhole logging measurements.
Site 1

Site 2

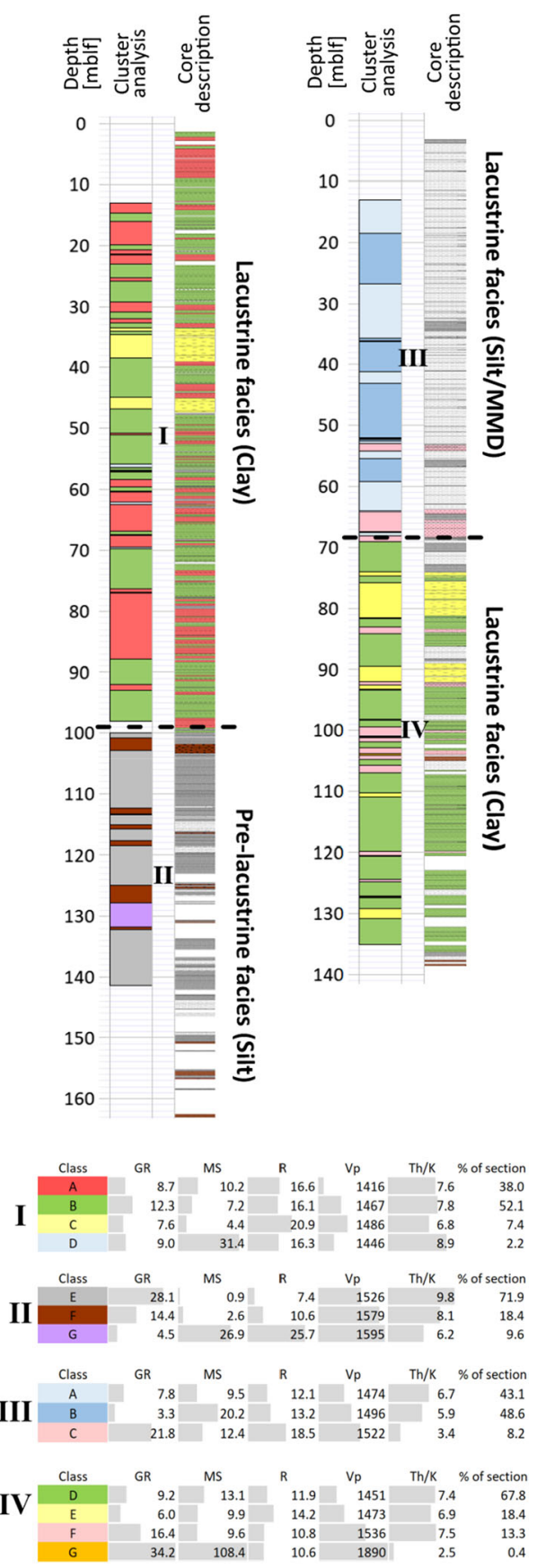

Fig. 4 Created cluster logs from Site 1B (left) and Site 2C (right) compared to core description data. Physical properties of the cluster log are given in tables below. Roman numerals stand for one cluster analysis each. The dashed line indicates the border of the two clustered sections at each site 
Cluster analysis II (Site 1B, 141-100 mblf,

fluviolacustrine facies)

The classes as derived from cluster analysis differ mainly with respect to their GR. Class E is characterized by high GR and dominates the section $(\sim 72 \%)$. Class F is characterized by medium GR, but low MS. It can be connected to peat layers. Major core loss in the fluviolacustrine facies made it difficult to make definitive conclusions. Class $G$ is characterized by low GR and higher MS, R and Vp. Missing core material in the interval 132.5-126 mblf prohibits verification with a specific sediment layer.

Site $2 C$

As at Site 1B, two separate cluster analyses were conducted using detrended data for the upper and lower lithologic units. Since neither cluster analysis over the full $\log$ (135-13 mblf), nor major shifts in logged parameters (ESM Fig. S2) indicated changes in lithology, the decision about the coverage of the sections for cluster analyses was based on the core description from Russell et al. (2016). Division into classes was based on physical properties. The upper part, 68-13 mblf was divided into three classes (A-C), whereas the lower part of the section was divided into four classes (D-G, Fig. 4, right).

\section{Cluster analysis III (Site 2C, 68-13 mblf, mass movement deposits MMD)}

The upper $68 \mathrm{~m}$ of sediments at Site 2 consist mainly of MMD. Compared to class A, class B has lower GR and higher MS. Comparison of cluster classes with core data highlights the limit of cluster analysis in this section. A clear correlation of class A or B to lithologic units is not possible here. In contrast, class $C$ can clearly be connected to thick tephra layers in the core. It is characterized by high GR and R.

\section{Cluster analysis IV (Site 2C, 135-68 mblf, lacustrine facies)}

The log of this depth interval is dominated by class $\mathrm{D}$ ( $\sim 68 \%$ ), with intermediate GR and higher MS. It corresponds to clay from the core description. Class $\mathrm{E}$ has the lowest GR and the highest $\mathrm{R}$ and is correlated to diatomaceous ooze in most parts. Class $F$ is characterized by high GR and low MS. Many tephra layers correlate to this class. In general, tephra layers in the core are thin, but some of the thicker ones are identifiable in the cluster log. Class $G$ appears as a single 30-cm-thick layer at 104 mblf. Compared to other classes, it has extraordinarily high GR, MS and $\mathrm{Vp}$ values. The latter indicate a dense material, which is consistent with core analysis that described an interbedded sandstone/shale layer at this depth.

\section{Cyclostratigraphy}

The MS and GR records of the lacustrine facies at Site $1 \mathrm{~B}$ were used for cyclostratigraphic analysis. The MS record that was used has a length of $84 \mathrm{~m}$, from the base of the lacustrine facies at 98 mblf to 10.4 mblf (Fig. 3), minus $3.65 \mathrm{~m}$ of excluded event layers. The analyzed GR record spans from 94.4 to 2 mblf and thus covers a broader depth range. We found a window size of $17 \mathrm{~m}$ for the sliding-window method (Molinie and Ogg 1990) useful, therefore the depth range of amplitude spectra was 85.9-18.9 mblf for MS and 85.9-10.5 mblf for GR, with half of the window size removed from each end of the record (ESM Fig. S3). The step size of the sliding window was set at $0.5 \mathrm{~m}$, resulting in an estimated sedimentation rate every 0.5 m.

Assuming an average sedimentation rate of $9.0 \mathrm{~cm} /$ ka for the investigated interval, suggested by the date on tephra T18 of $797 \mathrm{ka}$ at 72.05 mblf (Russell et al. 2020), the frequencies at which orbital cycles should be expressed in the amplitude spectra are 0.10 cycles/ $\mathrm{m}$ for a $\sim 110$-ka eccentricity component (combination of $95 / 125 \mathrm{ka}$ cycles), and 0.27 cycles/m for the 41-ka obliquity cycle. Precession-related cycles do not appear in the spectra and therefore, the high-frequency area is not illustrated (Fig. 5, ESM Fig. S3).

The amplitude spectra of the MS and GR datasets do not allow unambiguous interpretation of astrochronological cycles over the full depth. Therefore, multiple correlation options were explored (ESM Fig. S3). In the case of MS, the tracked amplitude peak splits three times, resulting in major shifts of more than $20 \mathrm{~cm} / \mathrm{ka}$ in SR estimations in those intervals (Fig. 5, ESM Fig. S3 left).

In the case of GR, two distinct peaks at approximately 0.09 cycles $/ \mathrm{m}$ and 0.24 cycles $/ \mathrm{m}$, appear in the amplitude spectrum (ESM Fig. S3 right). SR for both were calculated assuming that the corresponding lines 


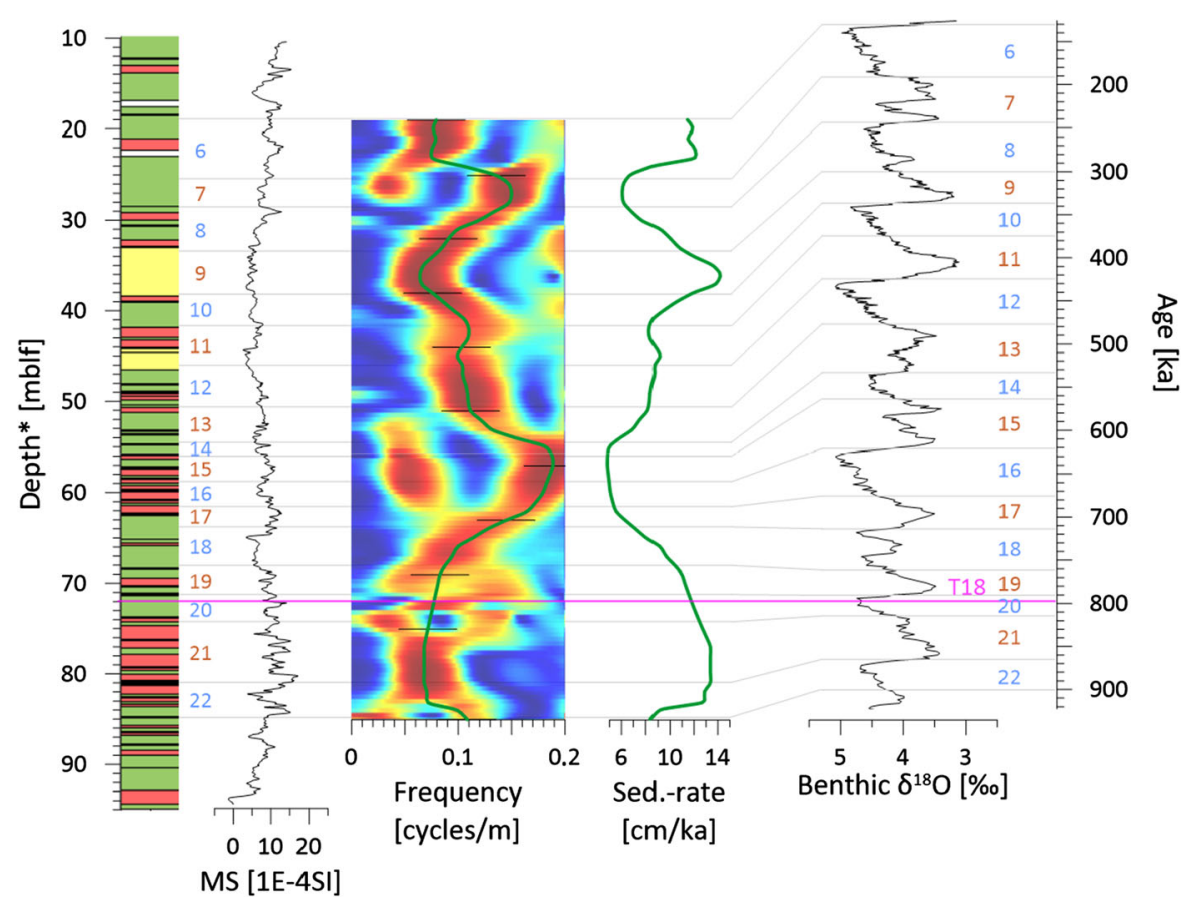

Fig. 5 Comparison (from left to right) of lithology, the magnetic susceptibility without event layers (MS), the amplitude spectrum, estimated sedimentation rates, the LR04 benthic stack (Lisiecki and Raymo 2005) and age, including marine

in the amplitude spectrum are related to the 110-ka eccentricity cycle (dark red and red line), whereas the orange line is interpreted as a 41-ka obliquity cycle. Major differences are expressed in the interval from 75 to 45 mblf, where sedimentation rates for the dark red line drop to $<5 \mathrm{~cm} / \mathrm{ka}$ (Fig. 5, ESM Fig. S3 right).

The calculated SR enabled construction of agedepth models for the investigated intervals (ESM Fig. S4). Tied to one data point (tephra T18 with a date of $797 \mathrm{ka}$ at 72.05 mblf depth*, from Russell et al. 2020), the constructed age-depth graphs vary. Three of the age-depth models form a cluster, with ages of approximately $370 \mathrm{ka}$ at a depth* of 20 mblf. Assuming this date is accurate, SR in the upper 20 mblf would have to slow considerably. One age-depth model calculated from GR intersects the depth axis at $20 \mathrm{mblf}$ and can thus be excluded from further discussion. One model, calculated from MS, reached an age of approximately $131 \mathrm{ka}$ at a depth of $19 \mathrm{mblf}$ (Fig. 6, ESM Fig. S4). The maximum calculated age of $903 \mathrm{ka}$ at a depth* of 85.9 mblf resulted in a total span of isotope stages. Tephra T18 in pink is the age-control point (Russell et al. 2020). Marine isotope stages (MIS) are colored in blue for glacials and brown for interglacials. (Color figure online)

$772 \mathrm{ka}$ and represents the time from late MIS 23 to late MIS 6.

\section{Discussion}

It is difficult to interpret paleoenvironmental conditions from the downhole logging data. Differences in the main lithologies of the lacustrine facies are reflected in relatively weak changes in sediment physical properties. Hence, distinction between the main sediment types "clay" and "sideritic clay" is impractical from single downhole logging measurements alone. Particular sediment types, like diatomaceous ooze and MMD, show strong geophysical characteristics that make them interpretable. Highamplitude variations in downhole logging data from the fluviolacustrine facies may be caused by rapid environmental changes and/or tectonically driven variability in the depositional sedimentary system (Russell et al. 2016). 


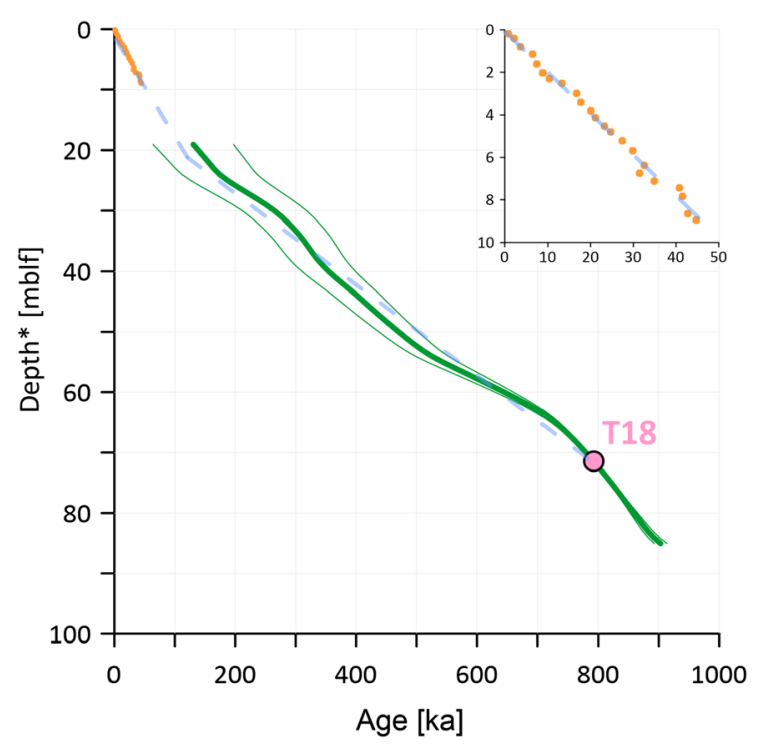

Fig. 6 Age-depth model from interpreting cyclicity of the magnetic susceptibility data, as related to $\sim 110$-ka eccentricity. Effects of $\pm 10 \%$ uncertainty in amplitude tracking is indicated as thin lines. Orange data are ${ }^{14} \mathrm{C}$ ages from Russell et al. (2014). The dated tephra (T18) is displayed in pink. Note the increase of uncertainty with increasing distance to T18. Inset: detailed view of ${ }^{14} \mathrm{C}$ ages in the upper $10 \mathrm{~m}$ (50 ka) of the record from a piston core collected close to Site 1. (Color figure online)

The strongest peak in $\mathrm{Vp}$ coincides with distinctive peaks in $\mathrm{R}$ and MS, but a drop in GR in Unit 2 at Site 1B ( 130-126.5 mblf). This leads to a clear separation from other classes in the cluster analysis (Figs. 3, 4). The mentioned variables indicate the presence of an exceptional layer consisting of dense material with high $\mathrm{R}$ and high $\mathrm{MS}$, e.g. a lateritic paleosol. The abrupt increase in conductivity, from 0.27 to $0.55 \mathrm{mS} / \mathrm{cm}$ may have been caused by humic acids leaking from a peat layer into the borehole. Major core loss in this part of the profile, however, prohibits a clear determination. A second layer with similar values occurs at $\sim 150-148$ mblf. As the sonic tool was operated only at depths above 141.5 mblf, this was not part of the cluster analysis.

\section{Cluster analysis}

Cluster analysis is a useful tool for identification and classification of lithologic units. One constraint, however, is that sediment cores are necessary to verify initial results. Nevertheless, if successful, the results of the cluster analysis can be transferred to other holes and logging sites, and fill coring gaps. Careful preprocessing to eliminate external factors, e.g. interaction of drilling fluids with the borehole wall, are indispensable for robust results.

The characteristics of lithologic units are given in Fig. 4. The logs were detrended before analysis, but the relative values of variables still provide information about sediment characteristics. Values of class A and B in cluster analysis I (Fig. 4, Site 1B, 13-98 mblf) illustrate the difficulties of differentiation. The two classes are similar in their physical properties, whereas classes $\mathrm{C}$ and $\mathrm{D}$ each have at least one physical variable that distinguishes them from the other classes. In the lower part of Site 1, lithologies and thus physical properties of the sediments vary substantially. This results in stronger differentiation of lithologic units. Several layers of class F can be assigned to peat in the core. The exceptional layer discussed earlier appears as a single $\sim 3.5$-m-thick layer (class G) around $\sim 130$ mblf. Cluster analysis from downhole logging data is the only option to investigate depths with major core loss, for instance cluster analysis II from 141 to 100 mblf at Site 1B (Fig. 4).

Heterogeneity of the MMD at Site $2 \mathrm{C}$ illustrates the limits of cluster analyses. Although different physical properties (especially MS) result in classification into class $\mathrm{A}$ and $\mathrm{B}$, similarities to core description are not apparent. Only class C can be linked clearly to tephra in the core. After applying the same cluster analysis properties to the lacustrine facies at Site 2 (cluster analysis IV, Fig. 4, Site 2C, 135-68 mblf), the comparison of cluster analysis and core lithology is similar to the lacustrine facies at Site 1 (cluster analysis I, Fig. 4, Site 1, 98-13 mblf), except for the identification of tephra layers, which tend to be thicker at Site 2 and thus better recorded by downhole logging tools.

Data from core scanning (X-ray Fluorescence or MSCL) would improve results, but problems like core loss or small depth shifts caused by sediments slipping in the core liners during recovery/transport preclude the creation of continuous data sets. The use of more downhole variables (e.g. element concentrations, neutron porosity) is recommended, but not implementable in international drilling campaigns because of the difficulty of exporting/importing radioactive sources. 
Cyclostratigraphy and an age-depth model

The sedimentary succession in Lake Towuti is the result of interactions among the geologic, hydrologic and sedimentary systems in the lake catchment. Factors including tectonic activity and lake connectivity might influence the signal in Lake Towuti, given their potential to change the geologic and hydrologic environment around the lake. Another factor that can modify the MS signal is the formation of magnetic minerals during diagenesis. Such changes are, however, at least partly climate-driven and thus contain information about local climate evolution and astronomical insolation forcing. Here we discuss the extent of the orbital imprint and factors that may affect the orbital signal in the sediments.

A reasonable age-depth model was derived from the MS record, by tracking amplitude peaks with frequencies between 0.06 and 0.19 cycles $/ \mathrm{m}$, and interpreting them as a 110-ka cycle (Fig. 5), related to eccentricity or glacial/interglacial climate variability. Anchored to the dated tephra from Russell et al. (2020), and combined with ${ }^{14} \mathrm{C}$ data from Russell et al. (2014), the age-depth model shown in Fig. 6 covers more than $77 \%$ of the history of the lacustrine facies at Site 1B, clearly improving our understanding of the age and extent of the sediment record in Lake Towuti. Other configurations of orbital cycles, and interpretations of age-depth models from MS or GR were tested, but failed to describe the sedimentological history of Lake Towuti in the published stratigraphic context (ESM Figs. S3 and S4).

Our results, referring to the dominance of a 110-ka cycle, agree with the eccentricity-related, glacialinterglacial cycles that were the predominant driver of global climate over the last $\sim 1$ Ma. Also, several other regional records from the Solomon Sea in the southwestern Pacific were driven mainly by an eccentricity component during the last $\sim 1 \mathrm{Ma}$ and support our understanding of the regional changes in the Indo Pacific Warm Pool (Chuang et al. 2018). Records of IPWP sea surface temperature, derived from foraminifera $\mathrm{Mg} / \mathrm{Ca}$ ratios and/or alkenone paleotemperature determinations, show a dominant 100-ka cycle similar to the benthic LR04 $\delta^{18} \mathrm{O}$ stack (de Garidel-Thoron et al. 2005; Herbert et al. 2010; Lisiecki and Raymo 2005). Speleothem records from northern Borneo, which span the last $160 \mathrm{ka}$, show patterns of precession in their records (Carolin et al.
2016), but like the Towuti record, these cycles play a subordinate role to glacial-interglacial variability (ESM, "Testing for particular cyclicities").

It should be possible to resolve individual precession cycles in lake sediments from tropical environments. This, however, was not the case here, possibly because of generally weak expression of precession in sediments from Lake Towuti. In our opinion, complex sedimentology, including different geochemical signatures and tephra layers, prevent precession signals from being identified clearly in downhole geophysical logs. The signal of a 110-ka eccentricity cycle in our interpretation shifts or vanishes at some stages in the amplitude spectrum, which complicates robust, unambiguous interpretation. Two of those shifts appear in the MS data at $\sim 56$ and $\sim 26$ mblf, where sedimentation rates clearly differ between the paths in amplitude tracking (Fig. 5).

\section{Uncertainties of the cyclostratigraphy}

The main uncertainty is caused by the complex regional setting, where multiple factors can distort orbital signals in the sediment. Enhanced biological activity (diatomaceous ooze) and event layers (MMD/ tephras) cause major changes in the absolute amount of deposited material. This can result in an apparent rise of sedimentation rates, making frequency-tracking difficult.

The age model was constructed using only the single dated tephra layer T18, with an age of $797 \mathrm{ka}$ at 72.05 mblf depth* (Russell et al. 2020). The estimated uncertainty is displayed in Fig. 6, where the effect of $\mathrm{a} \pm 10 \%$ shift in the tracked frequency results in an age range of $131 \pm 67 \mathrm{ka}$ at $\sim 19$ mblf. In general, sedimentation rate estimates are based on tracking individual peaks in the amplitude spectra. Peaks, however, are characterized by a wider frequency range because the window size here was $17 \mathrm{~m}$, enabling multiple options for tracking maxima. Also, the size of the sliding window has an effect on uncertainty. The peaks displayed at every step in the amplitude spectra represent values averaged over the 17-m window size. These uncertainties have to be considered when developing and interpreting this age-depth model.

To interpret peaks in the amplitude spectrum as eccentricity or obliquity cycles, we used the average sedimentation rate of $\sim 9 \mathrm{~cm} / \mathrm{ka}$, calculated between T18, with an age of $797 \mathrm{ka}$ at $72.05 \mathrm{mblf}$, and the 
water-sediment interface. This results in frequencies of 0.10 cycles $/ \mathrm{m}$ for the 110 -ka eccentricity cycle, and $0.27 \mathrm{cycles} / \mathrm{m}$ for the $41-\mathrm{ka}$ obliquity cycle. Commonly, SR changes over time, allowing a wider range for interpretation of orbital cycles (e.g. a range of $0.18-0.06 \mathrm{cycles} / \mathrm{m}$ for the $110 \mathrm{ka}$ eccentricity cycle, with SR from 16 to $5 \mathrm{~cm} / \mathrm{ka}$ ).

\section{Paleoenvironmental indications}

The records of MS and benthic $\delta^{18} \mathrm{O}$ seem to follow a similar trend from MIS 17 to 12, but in other parts this relation is not evident (MIS 19-17 and 10-6) or even opposite (MIS 20 and 11; Fig. 5). According to Tamuntuan et al. (2014), MS reflects the response of the system to lake level fluctuation and thus, wetter or dryer periods. This relationship seems to continue in the younger part (MIS 9-6), though not as clearly. Sideritic clay is restricted to glacials, despite the main portion of the glacials consisting of clay (Fig. 5). Enhanced bioproductivity during MIS 9 might have resulted in diatom blooms leading to increased SR. This can be seen in a peak in the SR at 36 mblf related to a diatomite layer. Yet the two diatomaceous ooze layers are a factor of uncertainty, since the exact amount of time contributed to the normal background sedimentation of clays is unknown. In the part of the record older than MIS 10, the relationship between clay type and glacial/interglacial variability is not very clear. Although there is clear cyclicity, the patterns can only tentatively be matched to LR04. This leads to the conclusion that factors other than the glacial/ interglacial cyclicity played an important role in the deposition of certain clay types, and thus the oxidation state, in the older section of Lake Towuti. These factors include tectonically induced changes of the basin structure, changes in the hydrological environment and/or diagenetic processes. Quantifying these factors is beyond this study, but should be evaluated to establish the full context of sedimentary processes in Lake Towuti. Despite several uncertainties in this highly complex, non-linear sedimentary system, we see distinct cycles related to eccentricity and/or glacial/interglacial climate variability (a combination of 125-ka and $95 \mathrm{ka}$ cycles) in our record. Even if the complete record of Lake Towuti's history was not covered by our investigations, we obtained a useful estimate of the range in SR, between 5 and $14 \mathrm{~cm} / \mathrm{ka}$.

\section{Conclusions}

Downhole logging data from Lake Towuti are valuable, but challenging in several aspects. First, low variability of physical properties of the sediments makes it difficult to distinguish between different classes in the cluster analysis. Cluster analysis, however, is an appropriate tool to distinguish major lithologic units, and is the only way to characterize the sediment physical properties and make determinations about lost core material (Fig. 4).

A second challenge is identification and interpretation of sedimentation cycles, a difficulty caused by the shortness of the record. The investigated magnetic susceptibility record has a length of $84 \mathrm{~m}$ and a maximum age of $903 \pm 11 \mathrm{ka}$. This rather short record, with its limited number of sedimentary cycles, complicates astrochronological interpretation. Nevertheless, a link between different sedimentary environments and marine isotope stages is recognizable, albeit not very clear. The time interval spanning the logging datasets is dependent on the selection of the tracked amplitude in the spectra. For the magnetic susceptibility record, the time span covered by the tracked data is $772 \pm 67 \mathrm{ka}$ and likely represents Lake Towuti's sedimentological history most accurately (Fig. 6).

The third challenge is the determination of the calculated sedimentation rate, and the age-depth model, using only a single fixed data point (tephra T18). Despite accurate measurement of the date on this layer, errors of just a few 1000 years may result in shifts of the whole record. Thus, additional agecontrol points are required to construct a more detailed age-depth model from the logging data.

Acknowledgements This research project was funded by the German Research Foundation (DFG, Grant No. WO672/15-1. The Towuti Drilling Project was funded, in part, by grants from the International Continental Scientific Scientific Drilling Program (ICDP), the US National Science Foundation (NSF), the German Research Foundation (DFG, Grant No. ME 1169/2Rag6), the Swiss National Science Foundation (SNSF; 20FI21_153054/1 and 200021_153053/1), Brown University, Genome British Columbia, and the Ministry of Research, Technology and Higher Education (RISTEK). We thank the Towuti Drilling Project team for helpful discussions of results during and after post-drilling workshops. Our special thanks go to our technical staff, Thomas Grelle and Jan-Thorsten Blanke, for acquisition of geophysical downhole logging data on site, and Henrike Baumgarten and Cornelia Müller, for sample handling and laboratory work in the Leibniz Institute for 
Applied Geophysics. We also appreciate the work of anonymous reviewers and editors.

Open Access This article is licensed under a Creative Commons Attribution 4.0 International License, which permits use, sharing, adaptation, distribution and reproduction in any medium or format, as long as you give appropriate credit to the original author(s) and the source, provide a link to the Creative Commons licence, and indicate if changes were made. The images or other third party material in this article are included in the article's Creative Commons licence, unless indicated otherwise in a credit line to the material. If material is not included in the article's Creative Commons licence and your intended use is not permitted by statutory regulation or exceeds the permitted use, you will need to obtain permission directly from the copyright holder. To view a copy of this licence, visit http://creativecommons.org/licenses/by/4.0/.

Funding Open Access funding enabled and organized by Projekt DEAL.

\section{References}

An Z (2000) The history and variability of the East Asian paleomonsoon climate. Quart Sci Rev 19(1-5):171-187

Carolin SA, Cobb KM, Lynch-Stieglitz J, Moerman JW, Partin JW, Lejau S, Malang J, Clark B, Tuen AA, Adkins JF (2016) Northern Borneo stalagmite records reveal West Pacific hydroclimate across MIS 5 and 6. Earth Planet Sci Lett 439:182-193

Chuang C-K, Lo L, Zeeden C, Chou Y-M, Wei K-Y, Shen C-C, Mii HS, Chang YP, Tung Y-H (2018) Integrated stratigraphy of ODP Site 1115 (Solomon Sea, southwestern equatorial Pacific) over the past 3.2 Ma. Mar Micropaleontol 144:25-37

Costa KM, Russell JM, Vogel H, Bijaksana S (2015) Hydrological connectivity and mixing of Lake Towuti, Indonesia in response to paleoclimatic changes over the last 60,000 years. Palaeogeogr Palaeoclimatol Palaeoecol 417:467-475

De Deckker P (2016) The Indo-Pacific Warm Pool: critical to world oceanography and world climate. Geosci Lett 3(1):20

de Garidel-Thoron T, Rosenthal Y, Bassinot F, Beaufort L (2005) Stable sea surface temperatures in the western Pacific warm pool over the past 1.75 million years. Nature 433(7023):294

Gebhardt AC, Francke A, Kück J, Sauerbrey MA, Niessen F, Wennrich V, Melles M (2013) Petrophysical characterization of the lacustrine sediment succession drilled in Lake El'gygytgyn, far East Russian Arctic. Clim Past 9:1933-1947

Herbert TD, Peterson LC, Lawrence KT, Liu Z (2010) Tropical ocean temperatures over the past 3.5 million years. Science 328(5985):1530-1534
Konecky BL, Russell JM, Bijaksana S (2016) Glacial aridity in central Indonesia coeval with intensified monsoon circulation. Earth Planet Sc Lett 437:15-24

Lehmusluoto P, Machbub B, Terangna N, Rusmiputro S, Achmad F, Boer L, Brahmana SS, Priadi B, Setiadji B, Sayuman O, Margana A (1995) National inventory of the major lakes and reservoirs in Indonesia. Expedition Indodanau Technical Report, Edita Oy

Lisiecki LE, Raymo ME (2005) A Pliocene-Pleistocene stack of 57 globally distributed benthic $\delta^{18} \mathrm{O}$ records. Paleoceanography 20(1):PA1003

Melles M, Bringham-Grette J, Minyuk P, Nowaczyk N, Wennrich V, DeConto R, Anderson PM, Andreev AA, Coletti A, Cook TL, Haltia-Hovi E, Wagner B (2012) 2.8 Million years of arctic climate change from Lake El'gygytgyn. NE Russia. Science 337(6092):315-320

Meyers SR (2014) Astrochron: an R package for astrochronology. https://cran.r-project.org/package=astrochron

Molinie AJ, Ogg JG (1990) Sedimentation rate curves and discontinuities from sliding-window spectral analysis of logs. Log Anal 31(06):370-374

Russell JM, Bijaksana S (2012) The Towuti drilling project: paleoenvironments, biological evolution, and geomicrobiology of a tropical Pacific lake. Sci Drill 14:68-71

Russell JM, Vogel H, Konecky BL, Huang Y, Melles M, Wattrus N, Costa K, King JW (2014) Glacial forcing of central Indonesian hydroclimate since 60,000 y BP. Proc Natl Acad Sci 111(14):5100-5105

Russell JM, Bijaksana S, Vogel H, Melles M, Kallmeyer J, Ariztegui D, Crowe S, Fajar S, Hafidz A, Haffner D, Hasberg A, Ivory S, Kelly C, King J, Kirana K, Morlock M, Noren A, O'Grady R, Ordonez L, Stevenson J, von Rintelen T, Vuillemin A, Watkinson I, Wattrus N, Wicaksono S, Wonik T, Bauer K, Deino A, Friese A, Henny C, Imran, Marwoto R, Ngkoimani LO, Nomosatryo S, Safiuddin LO, Simister R, Tamuntuan G (2016) The Towuti Drilling Project: paleoenvironments, biological evolution, and geomicrobiology of a tropical Pacific lake. Sci Dril 21:29-40

Russell JM, Vogel H, Bijaksana S, Melles M, Deino A, Hafidz A, Haffner D, Hasberg AKM, Morlock M, von Rintelen T, Sheppard R, Stelbrink B, Stevenson J (2020) The late quaternary tectonic, biogeochemical, and environmental evolution of ferruginous Lake Towuti, Indonesia. Palaeogeogr Palaeoclimatol Palaeoecol 556:109905

Stockhausen H, Zolitschka B (1999) Environmental changes since 13,000 cal. BP reflected in magnetic and sedimentological properties of sediments from Lake Holzmaar (Germany). Quat Sci Rev 18(7):913-925. https://doi.org/ 10.1016/s0277-3791(99)00005-0

Tamuntuan G, Bijaksana S, King J, Russell JM, Fauzi U, Maryunani K, Aufa N (2014) Variation of magnetic properties in sediments from Lake Towuti, Indonesia, and its paleoclimatic significance. Palaeogeogr Palaeoclimatol Palaeoecol 420:163-172

Team R C (2020) R: a language and environment for statistical computing. R Foundation for Statistical Computing, Vienna, Austria. https://www.R-project.org/

Vogel H, Russell JM, Cahyarini SY, Bijaksana S, Wattrus N, Rethemeyer J, Melles M (2015) Depositional modes and 
lake-level variability at Lake Towuti, Indonesia, during the past 29 kyr BP. J Paleolimnol 54(4):359-377

Vuillemin A, Friese A, Alawi M, Henny C, Nomosatryo S, Wagner D, Crowe SA, Kallmeyer J (2016) Geomicrobiological features of ferruginous sediments from Lake Towuti, Indonesia. Front Microbiol 7:1007

Wang Y, Cheng H, Edwards RL, Kong X, Shao X, Chen S, Wu J, Jiang X, Wang X, An Z (2008) Millennial- and orbitalscale changes in the East Asian monsoon over the past 224,000 years. Nature 451(7182):1090-1093

Ward JH Jr (1963) Hierarchical grouping to optimize an objective function. J Am Stat Assoc 58:236-244

Weedon GP (2003) Time-series analysis and cyclostratigraphy; examining stratigraphic records of environmental cycles. Cambridge University Press, Cambridge
Wicaksono SA, Russell JM, Bijaksana S (2015) Compoundspecific carbon isotope records of vegetation and hydrologic change in central Sulawesi, Indonesia, since 53,000 yr BP. Palaeogeogr Palaeoclimatol Palaeoecol 430:47-56

Yan XH, Ho CR, Zheng Q, Klemas V (1992) Temperature and size variabilities of the Western Pacific Warm Pool. Science 5088:1643-1645

Publisher's Note Springer Nature remains neutral with regard to jurisdictional claims in published maps and institutional affiliations. 